\title{
Disruption of reproductive behaviour of black caiman, Melanosuchus niger in the Santo Antônio hydroeletric dam, Madeira River, Brazilian Amazon
}

\author{
ZILCA CAMPOS
}

Embrapa Pantanal CP109 Corumbá, MS 79320900, Brazil

Author e-mail: zilca.campos@embrapa.br

\begin{abstract}
A female black caiman (Melanosuchus niger) was monitored by radio transmitter for three years in the area of Santo Antônio hydroelectric dam in Amazonia. Her nest was inundated during the formation of the reservoir and she abandoned the area and moved to a stream. It is recommended that the formation of new reservoirs is avoided in the three months from October to December to allow caimans to hatch from their eggs before inundation.
\end{abstract}

\section{INTRODUCTION}

$T^{\mathrm{h}}$ he black caiman (Melanosuchus niger), one of the largest caiman species in South America, faces several threats to its conservation (Da Silveira \& Thorbjarnason, 1999). Hydroeletric dams (HD) have been cited as a potential threat to M. niger in Brazil (Marioni et al., 2013), for example large individuals ( $S V L>2.00 \mathrm{~m}$ ) may die while attempting to cross the reservoir of the Santo Antônio HD (Campos, 2015). Females $M$. niger select more isolated environments when they reach reproductive age, a snout-vent length (SVL) of 100 to $120 \mathrm{~cm}$ or 15 to 20 years of age (Villamarin et al., 2011; Da Silveira et al., 2013), and in Amazonia lay eggs at the end of the dry season, between September and December. Like other crocodilians, $M$. niger females guard their nests and young hatchlings (Herron et al., 1990). In this study, I examine how rising water levels caused by closure of the Santo Antônio HD affected $M$. niger reproduction on an island in the Madeira River, in the Amazon.

\section{MATERIAL AND METHODS}

On 24 June 2011, a reproductive female was captured at night in the area of the Santo Antônio HD reservoir in Rondônia, Brazil, near the Ilha dos Búfalos. A radiotransmitter (Telonics, MOD 400) was fitted to her tail, and tracked with a TR-4 receiver and $2 \mathrm{H}$ antenna (TELONICS). The female was monitored from 24 June 2011 to 17 December 2013. The reservoir was filled on 24 November 2011, causing the Madeira River mean water level to rise from 8.8 to 13.95 $\mathrm{m}$, reaching a level of $19.86 \mathrm{~m}$ at the peak of the rainy season in April 2012 (Campos et al., 2017).

From 28 October to 02 November 2011, searching for $M$. niger nests was undertaken on foot by three people on the Ilha dos Búfalos in the Madeira River $\left(9^{\circ} 9^{\prime} 55.14^{\prime \prime} \mathrm{N}\right.$ $\left.64^{\circ} 31^{\prime} 17.47^{\prime} \mathrm{W}\right)$. The Ilha dos Búfalos covers an area of 14 $\mathrm{km}^{2}$ with meanders of the Madeira River and dense forest. The nests were opened and the eggs counted and weighed.
One egg was collected to measure the total embryo length to give an estimate of its age (Vieira et al., 2011) and at this time a second female was captured next to her nest and measured. Nests and young hatchlings on the Ilha dos Búfalos were monitored between 15 and 17 December 2011, and those in a rainforest stream on the left bank of Madeira River were monitored in November and December 2012 and 2013.

\section{RESULTS}

Twelve $M$. niger nests were found on the Ilha dos Búfalos, one of which was built by the female monitored by radio transmitter (Fig.1A and B). The number of eggs per nest varied from 28 to 48 (mean $=42.7, \mathrm{SD} \pm 6.57, \mathrm{~N}=10$ ), their mean length and width were $88.51 \mathrm{~mm}(\mathrm{SD} \pm 2.77$ ) and 58.87 $\mathrm{mm}(\mathrm{SD} \pm 1.45)$ respectively, and their mass varied from 124 to $161 \mathrm{~g}$ (mean=146.3, SD \pm 11.07$)$. The embryos varied in estimated age from 1 to 45 days, $(N=10)$, and peak egg laying occurred in October. The radio monitored female had a SVL of 152.3 and laid 45 eggs the second female captured next to her nest had a SVL of $150 \mathrm{~cm}$ and laid 43 eggs.

The radio monitored reproductive female arrived at Ilha dos Búfalos on 08 Jun 2011 and traveled $3 \mathrm{~km}$ to the breeding site, where she laid her eggs sometime between 22 and 27 October 2011. She remained near the nest until it was flooded, which probably occurred on 24 November 2011, when the water level of the Madeira River rose $5.5 \mathrm{~m}$. The female then left the flooded nest and departed from the island on 27 December 2011. She moved to the left bank of the Madeira River and entered a stream, where she remained until 19 December 2013 (Fig. 1B). This female apparently did not reproduce in the breeding seasons of 2012 and 2013 as night time searches for nests in her surroundings and for young hatchlings in her proximity were unsuccessful. The greatest distance this female caiman traveled in the period before the dam was closed was $3 \mathrm{~km}$, in the second year it was $2 \mathrm{~km}$ and in the third year it was only $120 \mathrm{~m}$. 


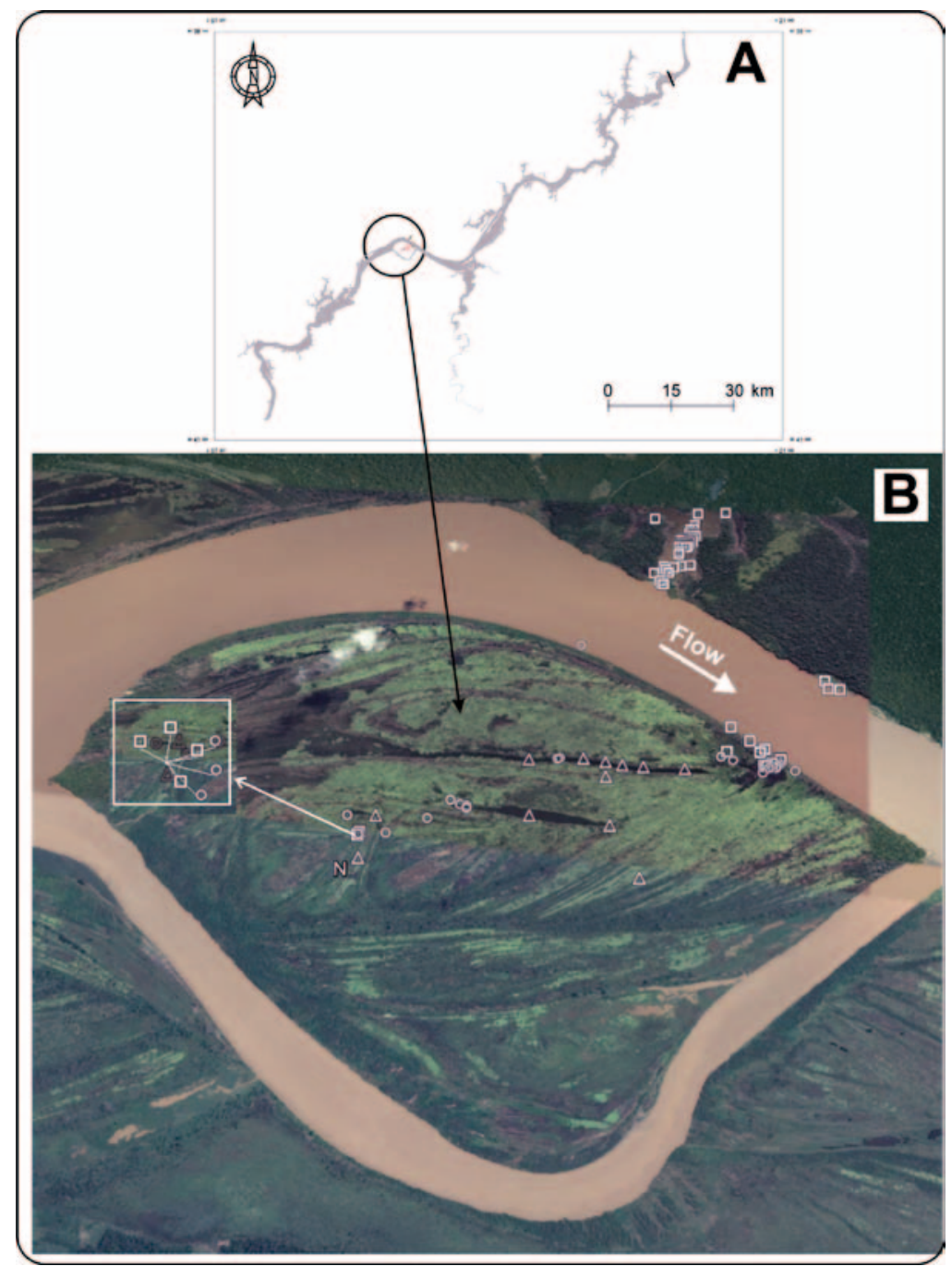

Figure 1. A. Area of the Santo Antônio HD reservoir, highlighting the llha dos Búfalos; B. Distribution of the 12 nests of $M$. niger (triangles), locations occupied by the female with the radio-transmitter before the formation of the reservoir (circles), the female beside her nest (N), locations occupied by the female after flooding (squares). She eventually moved from the llha dos Búfalos and entered a stream on the left bank of the River Madeira.

Of the 12 nests found on Ilha dos Búfalos, two were subject to predation, five were flooded when the reservoir was filled, while in the remaining five the caimans hatched successfully.

\section{DISCUSSION}

The closure of the Santo Antônio hydroelectric dam gates altered the reproductive behaviour of the $M$. niger female, since her nest was flooded on 24 November 2011 when the water level rose rapidly in the region of Ilha dos Búfalos. It is known that $M$. niger females select environments to reproduce according to the hydrological condition of the site, and an essential condition is for the water level to remain stable until hatching (Villamarin et al., 2011). The female stayed close to her nest until 30 November 2011, after which she left the island. The llha dos Búfalos was an area used by 12 breeding females at the end of the dry season of 2011, and was considered an environment conducive to $M$. niger reproduction prior to the construction of the hydroelectric plant. The female moved similar distances before and after the first year of flooding, i.e., $3 \mathrm{~km}$ and then $2 \mathrm{~km}$, but in the second year after the reservoir was filled, she remained more sedentary in the new environment that emerged, since the river had a constantly high level and the surrounding forests were flooded and dead.

The high density of $M$. niger nests $\left(0.86\right.$ nests $\left./ \mathrm{km}^{2}\right)$ on Ilha dos Búfalos indicates that many female caimans used it as their breeding site, but breeding success was reduced after the water level rose to fill the reservoir. Given that the female $M$. niger monitored in this study lost her nest to flooding and did not reproduce in the two subsequent years, it would be better if hydroelectric dam gates in the Amazon region with a similar hydrological regime to that of the Madeira River were closed only after the young $M$. niger have hatched from their eggs. Closure should start in December by which time most caiman will have hatched from their eggs.

\section{ACKNOWLEDGMENTS}

I thank the team of Santo Antônio Energia, particularly Ricardo and Adriene Alves, the support team of Ornelas, namely Aurimar Sarmento, Pedro Almeida, Thiago Rabelo, Daniel Martins, Marcos Moura, and Ronifran Gondini, and 
Eduardo Sábato (SETE Soluções). Thanks are also due to Claúdia Keller and Fábio Muniz of INPA (National Institute of Amazonian Research), and to Luís Alberto Pellegrin of Embrapa Pantanal for their assistance in this study. Special thanks for William E. Magnusson (INPA) for all the help. The caiman capture permit was issued by IBAMA (Brazilian Institute of Environment and Renewable Natural Resources).

\section{REFERENCES}

Campos Z. (2015). Size of caimans killed by humans at a hydroelectric dam in the Madeira River, Brazilian Amazon. Herpetozoa 28: 101-104.

Campos, Z., Mourão, G., \& Magnusson, W.E. (2017). The effect of dam construction on the movement of dwarf caimans, Paleosuchus trigonatus and Paleosuchus palpebrosus, in Brazilian Amazonia. PloS one, 12, e0188508.

Da Silveira, R., Magnusson, W.E. \& Campos, Z. (1997). Monitoring the distribution, abundance and breeding areas of Caiman crocodilus crocodilus and Melanosuchus niger in the Anavilhanas Archipelago, Central Amazonia, Brazil. Journal of Herpetology 31: 514-520.

Da Silveira, R., Valsecchi, J., Magnusson, W.E. \& Thorbjarnarson, J.B. (2011). Melanosuchus niger (Black Caiman). Long distance movement. Herpetological Review 42: 424-425.

Da Silveira, R., Campos, Z., Thorbjarnarson, J. \& Magnusson, W.E. (2013): Growth rates of black caiman (Melanosuchus niger) and spectacled caiman (Caiman crocodilus) from two different Amazonian flooded habitats. AmphibiaReptilia 34: 437-449.
Da Silveira, R. \& Thorbjarnarson, J. B. (1999). Conservation implications of commercial hunting of black and spectacled caiman in the Mamirauá Sustainable Development Reserve, Brazil. Biological Conservation 88: 103-109.

Herron, J.C., Emmons, L.H. \& Cade, J.E. (1990). Observations on reproduction in the black caiman, Melanosuchus niger. Journal of Herpetology 24: 314-316.

Marioni, B., Farias, I., Verdade, L.M., Bassetti, L., Coutinho, M.E., Mendonça, S.H.S.T., Vieira, T.Q, Magnusson, W.E. \& Campos, Z. (2013). Avaliação do risco de extinção do jacaré-açu Melanosuchus niger (Spix, 1825) no Brasil. Biodiversidade Brasileira 3: 31-39.

Vieira, L.C., Lima, F.C., Santos, A.L.Q., Mendonça, S.H.S.T., Moura, L.R., lasbeck, J.R. \& Sebben, A. (2011). Description of embrionic stages in Melanosuchus niger (Spix, 1825) (Crocodylia: Alligatoridae). Journal of Morphological Sciences 28: 11-22.

Villamarin, F., Marioni B., Thorbjarnarson J., Nelson, B., Botero-Arias R. \& Magnusson W.E. (2011). Conservation and management implications of nest-site selection of the sympatric crocodilians Melanosuchus niger and Caiman crocodilus in Central Amazonia, Brazil. Biological Conservation 144: 913-919.

Accepted: 15 May 2019 